\title{
Insulin, insulin resistance and platelet function: similarities with insulin effects on cultured vascular smooth muscle cells
}

\author{
M.Trovati, G. Anfossi \\ Diabetes Unit, Department of Clinical and Biological Sciences of the University of Turin, San Luigi Gonzaga Hospital, \\ Orbassano (Turin), Italy.
}

Keywords Insulin, Insulin resistance, Platelets, Vascular Smooth Muscle, Calcium, cGMP, cAMP, Nitric oxide, Prostacyclin.

\section{Introduction}

The relationships between insulin, insulin resistance and atherosclerosis are still a matter of intense debate [1-4] even though it was suggested as long as 30 years ago that insulin is involved in the pathogenesis of atherosclerosis [5]. It is not clear whether insulin plays the role of a culprit, an innocent bystander, a factor involved in the attenuation of some steps in the atherogenic process or an agent with multifaceted actions having different and possibly contrasting effects. The question is: is the prevalence of atherosclerosis in the insulin-resistant states due to hyperinsulinaemia or to the presence of cellular resistance to some anti-atherogenic insulin actions? To answer we need to know the mechanisms by which insulin influences the cells involved in the pathogenesis of atherosclerosis.

In this review we examine the way in which insulin affects platelet function. Platelets are essential ele-

Corresponding author: M. Trovati, MD, Diabetes Unit, Department of Clinical and Biological Sciences of the University of Turin, San Luigi Gonzaga Hospital, 10043 Orbassano (Turin), Italy

Abbreviations: VSMC, Vascular smooth muscle cells; $\mathrm{PGI}_{2}$, prostacyclin; NO, nitric oxide; NOS, nitric oxide synthase; TXA $_{2}$, Thromboxane $\mathrm{A}_{2} ; \mathrm{IP}_{2}$, phosphatidylinositol 4,5-bisphosphate; $\mathrm{IP}_{3}$, phosphatidylinositol 1,4,5-trisphosphate; DAG, diacylglycerol; $\mathrm{Ca}^{2+}$, calcium; PKC, protein kinase C; ADP, adenosine diphosphate; ATP, adenosine triphosphate; GTP, guanosine triphosphate; ATPase, adenosine triphosphatase; AVP, arginine vasopressin; AT II, angiotensin II; PAF, platelet activating factor; $\mathrm{PGE}_{1}$, Prostaglandin $\mathrm{E}_{1}$; : L-NMMA, $\mathrm{L}_{\mathrm{N}} \mathrm{N}_{-}$ monomethyl arginine; ET-1, endothelin 1. ments in the thrombotic and atherosclerotic processes because of their own functional properties and their ability to interact with endothelial and vascular smooth muscle cells (VSMC) [6]. As VSMC share common features in their contractile structure and its regulation with platelets [7] we also compare the effect of insulin and insulin resistance on these two types of cells. In particular we lay emphasis on the modulation of calcium fluxes, cyclic nucleotide concentrations, nitric oxide and prostacyclin actions.

\section{Basic information on platelet physiology}

Some information on platelet physiology is necessary to understand the insulin effects on platelets [8-12].

\section{Main events in platelet activation}

According to the "response to injury hypothesis" [6] atherosclerosis develops as a response to endothelial damage due to: hypercholesterolaemia, oxidized LDL, arterial hypertension, diabetes, cigarette smoking, hyperhomocysteinaemia, etc. When endothelial cells are damaged or lost, they are unable to produce vasodilating, anti-aggregating and antithrombotic substances such as prostacyclin $\left(\mathrm{PGI}_{2}\right)$, nitric oxide (NO), adenosine and heparin. In these conditions, platelets:

i) adhere to subendothelium by interacting with exposed collagen and other cytoadhesive proteins of basal membranes through specific surface glycoproteins;

ii) lose their resting dish-like shape, becoming sphere-like cells with pseudopods (shape change);

iii) metabolize the phospholipid-derived arachidonic acid into different eicosanoids, in particular, into thromboxane $\mathrm{A}_{2}\left(\mathrm{TXA}_{2}\right)$ which causes fibrino- 
gen binding to platelets, aggregation, granule secretion and vasoconstriction;

iv) show an activation of phospholipase $\mathrm{C}$, acting on the membrane phospholipid phosphatidylinositol 4,5-bisphosphate $\left(\mathrm{IP}_{2}\right)$ to produce the second messengers inositol 1,4,5-trisphosphate $\left(\mathrm{IP}_{3}\right)$ and diacylglycerol (DAG). $\mathrm{IP}_{3}$ increases cytosolic free calcium $\left(\mathrm{Ca}^{2+}\right)$ via a direct action on the $\mathrm{Ca}^{2+}$ stores contained in the dense tubular system and thereby activates $\mathrm{Ca}^{2+} /$ calmodulin-dependent protein kinases, whereas DAG directly activates protein kinase C (PKC) and, via PKC, phosphorylates proteins involved in the release reaction and increases cytosolic $\mathrm{pH}$;

v) interact with other platelets by forming aggregates;

vi) release their granule content in the extracellular space through the canalicular system and microtubular contractile proteins (release reaction);

vii) contribute to the activation of the coagulation cascade, since some intrinsic coagulation reactions occur preferentially on their surface;

viii) modulate fibrinolysis, since they contain both plasminogen activators and inhibitors;

ix) induce chemotaxis and proliferation of VSMC, since proteins contained in platelet granules exert chemotactic and proliferating effects on these cells;

$\mathrm{x})$ modulate vasomotion, since they release both vasodilating - such as adenosine-diphosphate (ADP) and adenosine-triphosphate (ATP) - and vasoconstricting substances ( $\mathrm{TXA}_{2}$ and serotonin).

Platelets are involved both in the early stages of atherosclerosis (VSMC chemotaxis, migration to the intima and proliferation) and in the advanced lesions: after plaque formation, they contribute to vessel occlusion by promoting vasoconstriction, activation of the coagulative system and intravascular thrombus formation. Platelets can be activated not only by components of the subendothelial layer but also by other physiologic mediators able to bind to specific receptors, such as ADP, thrombin, catecholamines, 5-hydroxytryptamine, arginine vasopressin (AVP), angiotensin II (AT II), platelet activating factor (PAF) and TXA .

\section{Role of cyclic nucleotides in the modulation of platelet function}

Intraplatelet $\mathrm{Ca}^{2+}$ is the final mediator of platelet functional changes [8-15]. Platelet agonists induce depletion-refilling of $\mathrm{Ca}^{2+}$ stores: i) by generating $\mathrm{IP}_{3}$, which promotes $\mathrm{Ca}^{2+}$ release from intracellular stores in the cytosol, followed by $\mathrm{Ca}^{2+}$ re-accumulation into the stores via a $\mathrm{Ca}^{2+}$-Adenosine triphosphatase $\left(\mathrm{Ca}^{2+}\right.$-ATPase); ii) by inducing an influx of $\mathrm{Ca}^{2+}$ from the extracellular space, directly by interaction with agonist receptors and indirectly by depletion of intracellular stores [13-15]. Similarly, $\mathrm{Ca}^{2+}$ fluxes are the main regulators of VSMC contraction [16-17].

Cyclic adenosine monophosphate (cAMP) and cyclic guanosine monophosphate (cGMP), the main inhibitory second messengers for platelet activation acting predominantly via specific protein kinases [18], reduce cytosolic $\mathrm{Ca}^{2+}$ by different mechanisms. In particular, cAMP: i) decreases binding of thrombin to its receptors [19]; ii) inhibits activation of phospholipase $\mathrm{C}$, with a consequent reduction of $\mathrm{IP}_{3}$ and DAG [20-21]; iii) interferes with processes distal to phospholipase $\mathrm{C}[21]$; iv) by stimulating the $\mathrm{Ca}^{2+}$ ATPase, enhances $\mathrm{Ca}^{2+}$ extrusion from platelets [22] and $\mathrm{Ca}^{2+}$ uptake by the dense tubular system [23]. cAMP, therefore, decreases intraplatelet $\mathrm{Ca}^{2+}$ by promoting its uptake into the internal stores and its extrusion from the cells.

Similarly, cGMP: i) inhibits agonist-induced $\mathrm{Ca}^{2+}$ mobilization from intracellular stores and $\mathrm{Ca}^{2+}$ influx determined by store depletion [24]; ii) reduces the activation of phospholipase $\mathrm{C}$ also at the level of G-proteins [25], iii) modifies processes following protein phosphorylation close to the effector system [26].

Furthermore, both cAMP and cGMP: i) prevent $\mathrm{Ca}^{2+}$-releasing activity of $\mathrm{IP}_{3}$ from stores by inducing phosphorylation of $\mathrm{IP}_{3}$ receptors [27]; ii) inhibit thrombin-dependent $\mathrm{Ca}^{2+}$ influx [28], and, via this mechanism, modulate the $\mathrm{Na}^{+} / \mathrm{H}^{+}$antiporter and reverse the thrombin-evoked alkalinization [29]. Owing to the importance of $\mathrm{Ca}^{2+}$ fluxes in platelet function, it is not surprising that the increase of either cAMP or cGMP should prevent the main platelet responses: phosphoinositide metabolism, $\mathrm{Ca}^{2+}$ elevation, protein phosphorylation, platelet aggregation and release reaction [20, 30-31]. Similar effects of cyclic nucleotides on $\mathrm{Ca}^{2+}$ fluxes in VSMC mediate their vasodilating properties [32-35].

\section{Modulation of cyclic nucleotide synthesis and catabolism}

It is useful to summarise the mechanisms of synthesis and catabolism because of the relevance of cyclic nucleotides in platelet function.

cAMP and cGMP are synthesized by adenylate cyclase and guanylate cyclase from ATP and guanosine triphosphate (GTP), respectively.

Adenylate cyclase is activated by substances coupled to specific $\mathrm{G}_{\mathrm{s}}$-proteins: prostaglandins, such as prostaglandin $\mathrm{E}_{1}\left(\mathrm{PGE}_{1}\right)$ and $\mathrm{PGI}_{2}$, through specific receptors [36-38]; adenosine through the purinergic receptor $\mathrm{A}_{2}$ [39]; catecholamines through $\beta_{2}$ adrenergic receptors [40] and $\mathrm{D}_{1}$ dopaminergic receptors [41]. The catalytic subunit of adenylate cyclase can be activated directly by forskolin [42]. Adenylate cy- 
clase is inhibited by substances activating receptors coupled to $\mathrm{G}_{\mathrm{i}}$-proteins; in particular, $\alpha_{2}$-adrenergic receptors [43] and $\mathrm{D}_{2}$ dopaminergic receptors [41]. Physiological substances able to stimulate adenylate cyclase activity, such as $\mathrm{PGE}_{1}$ and $\mathrm{PGI}_{2}$, exert anti-aggregating and vasodilating properties by increasing cAMP both in platelets and in VSMC [44] and play a key role in the prevention of atherosclerosis and thrombosis [45].

cGMP is synthesized in platelets through a soluble guanylate cyclase, inhibited by methylene blue and activated by nitro-vasodilators and NO [46]. NO, a diffusible substance with a half-life of a few seconds formed from L-arginine by oxidation of its guanidine-nitrogen terminal [47], is the main endothelialderived relaxing factor [48] and a powerful platelet inhibitor $[49,50]$. It is able to reduce platelet adhesion to the vessel wall [51], platelet aggregation [52], and platelet surface glycoprotein expression, including P-selectin and activated glycoprotein IIb-IIIa complex [53]. As in endothelium, NO is constitutively produced by a cytosolic NO-synthase (NOS) requiring calmodulin, $\mathrm{Ca}^{2+}$ and $\mathrm{NADPH}$, in platelets and megakaryocytes [54-58]. The aminoacid sequence of human platelet NOS has been identified [59]. Through their NOS activity, platelets produce detectable amounts of NO [60-61] able to exert physiological effects such as inhibition of additional platelet recruitment after platelet activation [62]. Analogues of $\mathrm{L}$-arginine, such as $\mathrm{L}-\mathrm{N}^{\mathrm{G}}$-monomethyl arginine ( $\mathrm{L}-$ NMMA), inhibit NO synthesis in a stereospecific manner [63]. NOS is also inhibited by methylene blue [64], a guanylate cyclase inhibitor [46]. With the help of NOS inhibitors it was possible to determine that platelet-derived NO regulates platelet function, the activation of which is enhanced in vivo by infusion of NOS inhibitors [65] and reduced by L-arginine, the NOS-substrate [66].

In human platelets, $\mathrm{PGI}_{2}$ and $\mathrm{NO}$, which modulate cAMP and cGMP respectively, act synergistically to inhibit aggregation [67-69]. This synergism is further enhanced in vivo, since NO activates cyclo-oxygenase via a cGMP-independent mechanism leading to the endothelial release of $\mathrm{PGI}_{2}$ and therefore promoting the synthesis of cAMP [70].

Both cAMP and cGMP are catalysed by phosphodiesterases, enzymes subdivided into at least seven families, with family-specific agonists and inhibitors, able to hydrolyse selectively cAMP and cGMP or both [71-72]. Platelets contain different phosphodiesterase families, among them: i) the cGMP-stimulated cAMP phosphodiesterase which hydrolyses both cAMP and cGMP; ii) the low Km cGMP-inhibited cAMP phosphodiesterase which is the most abundant in platelets and hydrolyses cAMP more effectively than cGMP; iii) the cGMP-specific phosphodiesterase [71]. Substances that increase cAMP by means of adenylate cyclase activation, such as $\mathrm{PGE}_{1}$,
$\mathrm{PGI}_{2}$, Iloprost (a $\mathrm{PGI}_{2}$ analogue) and forskolin, stimulate cAMP phosphodiesterase activity in platelets with a negative feed-back mechanism which regulates cAMP concentrations: this is particularly so in the case of the cGMP-inhibited cAMP phosphodiesterase [71]. Furthermore, nitro-vasodilators, which stimulate the production of cGMP by activating the soluble guanylate cyclase, cause a dose-dependent increase of cAMP also, since cGMP reduces cAMP catabolism by inhibiting the cGMP-inhibited cAMP phosphodiesterase [73].

In summary, platelet aggregation is deeply involved in atherothrombosis and requires important changes in platelet $\mathrm{Ca}^{2+}$ fluxes, with a final increase in intracellular $\mathrm{Ca}^{2+}$ content.

The cyclic nucleotides cAMP and cGMP, the platelet content of which is determined by a balance between the activity of anabolic and catabolic enzymes, are physiological inhibitory modulators of $\mathrm{Ca}^{+}$fluxes and, therefore, also of platelet aggregation. For this reason, the main mechanism by which platelet antagonists reduce platelet function is to increase cyclic nucleotide concentrations. A similar modulation of cyclic nucleotides regulates $\mathrm{Ca}^{2+}$ fluxes in VSMC and mediate vasodilation.

\section{Insulin influence on platelet function}

\section{Insulin receptors in platelets}

The insulin receptors in human platelets have a concentration per surface area similar to that described in other cells [74] and have a beta-subunit phosphorylated by the hormone itself [75-76]. In patients with Type II diabetes mellitus, the platelet insulin receptor number and affinity are reduced [77]. Platelets, therefore, are a site of the insulin action and can be subject to variation of insulin sensitivity.

\section{Insulin influence on platelet aggregation}

We observed that, if human platelets are incubated with physiological concentrations of insulin for short periods of time (3-20 min), they have a reduced aggregating response to agonists: ADP, thrombin, adrenaline, PAF, collagen and sodium arachidonate [78-83]. Similar results have been obtained by other authors who observed that insulin reduces AT IIand thrombin-induced platelet aggregation and attenuates AT II ability to increase thrombin-stimulated platelet aggregation [84]. The same insulin-induced reduction of platelet responses to agonists can be reproduced in vivo by a euglycaemic hyperinsulinaemic clamp or similar techniques [79, 81, 85, 86].

Some authors, however, did not observe a direct insulin action on platelet aggregation in vitro 
Table 1. Effects of insulin in platelets

- Activation of insulin receptors $\left(^{a}\right)$
- Increase of cGMP (NO-mediated) $\left({ }^{a}\right)$, as in VSMC
- Increase of cAMP (NO-mediated, possibly via cGMP), as in
VSMC
- Increased effects on cAMP of adenylate cyclase activators (NO-
mediated), as in VSMC
- Reduced $\mathrm{Ca}^{2+}$ fluxes elicited by $\mathrm{Ca}^{2+}$-mobilizing agents $\left(^{\mathrm{a}}\right)$, as in
VSMC
- Reduced agonist-elicited platelet aggregation $\left(^{\text {a }}\right)$
- Increased antagonist-induced platelet anti-aggregation
- Increased binding of anti-aggregating prostanoids to platelets
via receptor up-regulation, with an increase of their effects
- Decreased binding of catecholamines to platelets via $\alpha_{2}$-adre-
nergic receptor down-regulation, with reduction of adrenaline-
induced aggregation
- Increased platelet uptake of magnesium
- Increased platelet release of plasminogen activator

(a) it has been demonstrated that this insulin effect is reduced in the insulin-resistant states

[87-89]. Others, using huge, supra-physiological amounts of insulin $(100 \mathrm{nmol} / \mathrm{l})$, even noted an insulin-induced pro-aggregating effect [90] which was confirmed in our laboratory [91].

The physiological role of insulin in inhibiting platelet function could play a protective role in the prevention of thrombus formation and in the release of vasoactive mediators and chemotactic/mitogenic substances, thus contributing to reduce the pathological events of thrombosis, hypertension and atherosclerosis. Furthermore, if platelets were a site of insulin resistance, the associated loss of insulin's beneficial effects could play a role in the increase in cardiovascular risk [92, 93]. This intriguing hypothesis has been confirmed experimentally. In effect, in the insulin-resistant states of obesity, obese Type II diabetes mellitus and arterial hypertension, the anti-aggregating effect exerted by insulin is attenuated or lost [83, 84].

\section{Insulin and $\mathrm{Ca}^{2+}$ fluxes in platelets: similarities with VSMC}

Insulin attenuates the action of different agonists able to activate platelets with different receptor and post-receptor events $[78,79,84]$. This means that the hormone interplays with very basic mechanisms of platelet function.

We have already mentioned that a rise in intracellular $\mathrm{Ca}^{2+}$ is a crucial aspect of platelet activation [8-15]. In these cells, the AT II-stimulated increases in intracellular $\mathrm{Ca}^{2+}$ are attenuated by a 5-min in vitro incubation with physiological insulin concentrations $(70 \mu \mathrm{U} / \mathrm{ml})$; furthermore, insulin reduces the in- crease in cytosolic $\mathrm{pH}$ induced by AT II and by endothelin 1 (ET-1); finally, the insulin effects on $\mathrm{Ca}^{2+}$ fluxes are accompanied by a concomitant reduction of platelet aggregation in response to thrombin [84]. Interestingly, the same study shows that insulin, when added alone to platelets, induces a rapid and transient rise in free $\mathrm{Ca}^{2+}[84]$.

In cultured VSMC and mesangial cells, that are structurally similar to platelets as far as the $\mathrm{Ca}^{2+}$-regulated contractile processes are concerned $[7,16]$, insulin, even at physiological concentrations, attenuates $\mathrm{Ca}^{2+}$ fluxes and contractile responses to different vasoconstrictors (AT II, AVP, noradrenaline, serotonin, and ET-1) [94-107]. This direct insulin action, together with VSMC-endothelium interactions [106], could take part in the insulin-induced vasodilation documented by many studies in vivo, consideration of this is beyond the scope of this review.

Sites at which insulin acts in modulating intracellular $\mathrm{Ca}^{2+}$ content: evidence from studies in VSMC

To understand the mechanisms by which insulin reduces $\mathrm{Ca}^{2+}$ fluxes in platelets, we should consider similar effects in VSMC.

Since insulin inhibits $\mathrm{Ca}^{2+}$ responses elicited by different agonists [95, 98, 101, 104, 107], it is possible that its effects occur at a common point in the transmembrane signalling cascade: therefore, insulin probably does not interplay primarily with receptor binding of the different agonists. The vasoconstrictors tested generate $\mathrm{IP}_{3}$, which interacts with specific receptors in the sarcoplasmic reticulum membrane of VSMC, opening $\mathrm{Ca}^{2+}$ channels and permitting $\mathrm{Ca}^{2+}$ contained in the intracellular stores to diffuse from the sarcoplasmic reticulum to the cytosol [17, 108, 109]. Insulin, therefore, could reduce the increase of intracellular $\mathrm{Ca}^{2+}$ induced by agonists by attenuating $\mathrm{Ca}^{2+}$ release from the $\mathrm{IP}_{3}$-sensitive intracellular stores. This hypothesis has been confirmed experimentally in cultured rat VSMC, when a 20min insulin incubation did not alter basal intracellular $\mathrm{Ca}^{2+}$ concentrations, but reduced AT II-induced $\mathrm{IP}_{3^{-}}$ releasable $\mathrm{Ca}^{2+}$ flux, through a mechanism mimicked by treatment with the cGMP analogue 8-bromocGMP or with sodium nitroprusside, and blocked by the NOS inhibitor L-NMMA [102]. Interestingly, insulin did not modify AT II receptor affinity and density, AT II-stimulated phospholipase C activity or $\mathrm{IP}_{3}$ production [102] which demonstrates that it simply reduces the sensitivity of $\mathrm{Ca}^{2+}$ stores for $\mathrm{IP}_{3}$. Similar effects have been documented in porcine coronary artery VSMC [107]. The ability of insulin to reduce cytosolic $\mathrm{Ca}^{2}+$ by interplaying with intracellular $\mathrm{Ca}^{2+}$ fluxes stimulated by agonists is further confirmed by the persistence of insulin effects in the absence of extracellular $\mathrm{Ca}^{2+}[102,107]$. In our labora- 
tory, it has been observed that the insulin-induced platelet anti-aggregating effect is also maintained in a $\mathrm{Ca}^{2+}$-free medium [80].

Insulin is also able to decrease $\mathrm{Ca}^{2+}$ influx in VSMC by stimulating the $\mathrm{Na}^{+}-\mathrm{K}^{+}$ATPase pump [110-112], a transport system that is inhibited by ouabain. Based on the exchange of intracellular $\mathrm{K}^{+}$with extracellular $\mathrm{Na}^{+}$, stimulation of $\mathrm{Na}^{+}-\mathrm{K}^{+}$-ATPase results in hyperpolarization of the cell membrane and subsequent closure of voltage-dependent $\mathrm{Ca}^{2+}$ channels, resulting in a decrease of intracellular $\mathrm{Ca}^{2+}$ [113]. An insulin effect on this ion pump has been reported in different cell types in vitro [114, 115] and has been described in in vivo experiments [116]. In human platelets, ouabain increases both cytosolic $\mathrm{Ca}^{2+}$ and $\mathrm{Na}^{+}$by blocking $\mathrm{Na}^{+}-\mathrm{K}^{+}$countertransport [117]. By analogy it could also be hypothesized that insulin affects this cellular pump also in platelets. In the rare condition of thyrotoxic periodic paralysis, hyperinsulinaemia is accompanied by an elevated $\mathrm{Na}^{+}-\mathrm{K}^{+}$ATPase activity in platelets [118].

The insulin role in the regulation of the different $\mathrm{Ca}^{2+}$ transport systems in VSMC has been reviewed recently [119]. In any case, insulin reduces intracellular $\mathrm{Ca}^{2+}$ both in platelets and in VSMC, and, by this basic mechanism, attenuates both platelet activation and VSMC constriction.

\section{Attentuation of the insulin effects on platelet $\mathrm{Ca}^{2+}$ fluxes in insulin-resistant states: similarities with VSMC}

First, platelets from insulin-resistant animals and man (e.g. affected by arterial hypertension, obesity or Type II diabetes mellitus) exhibit increased cytosolic free $\mathrm{Ca}^{2+}$ concentrations in resting and stimulated conditions [84, 120-128]. A positive correlation between resting intracellular $\mathrm{Ca}^{2+}$ and serum insulin concentrations, an indirect marker of insulin resistance, has been observed [128]. The abnormalities in $\mathrm{Ca}^{2+}$ handling in platelets from insulin-resistant subjects could be due to a defective insulin action on $\mathrm{Ca}^{2+}$ fluxes. In particular: i) platelets from hypertensive subjects show higher basal and AT II-stimulated intracellular $\mathrm{Ca}^{2+}$ concentrations; ii) in the presence of arterial hypertension, the insulin-induced attenuation of $\mathrm{Ca}^{2+}$ responses to AT II is impaired; iii) serum insulin concentrations, a marker of insulin resistance, are correlated positively with the increases in intracellular free $\mathrm{Ca}^{2+}$ elicited by AT II in the presence of insulin, meaning that the greater insulin resistance is, the less effective insulin is in the attenuation of AT II-stimulated $\mathrm{Ca}^{2+}$ fluxes [84]. These results suggest that an attenuated insulin-induced inhibition of platelet responses stimulated by agonists is a manifestation of insulin resistance, potentially involved in platelet hyperactivity occurring in arterial hypertension [84].
Similar results have been obtained in obese, hypertensive Type II diabetic patients. In these subjects, the reduced ability of insulin to attenuate AT II-stimulated free $\mathrm{Ca}^{2+}$ concentrations is corrected by 12 weeks of antihypertensive treatment with $\mathrm{Ca}^{2+}$ channel blockers (isradipine or diltiazem). These results demonstrate that the removal of abnormalities in $\mathrm{Ca}^{2+}$ fluxes restores insulin sensitivity in platelets and suggest that increased cytosolic $\mathrm{Ca}^{2+}$ can be both a cause and consequence of insulin resistance [129].

Furthermore, in contrast to insulin sensitive subjects, providing insulin-resistant, hypertensive and hyperinsulinaemic subjects with insulin increases their platelet $\mathrm{Ca}^{2+}$ concentrations, suggesting that insulin resistance extends to the regulation of platelet $\mathrm{Ca}^{2+}$ metabolism [130].

A resistance to the insulin effects on $\mathrm{Ca}^{2+}$ fluxes has also been observed in VSMC of insulin-resistant animals, such as spontaneously hypertensive rats (SHR) and Zucker obese rats [97, 98, 131]. These data indicate that insulin resistance at the VSMC level contributes to the increased intracellular $\mathrm{Ca}^{2+}$ response to vasoconstrictors and to the enhanced vascular reactivity of the insulin-resistant states [132-134]. An altered VSMC intracellular $\mathrm{Ca}^{2+}$ metabolism, therefore, may be a fundamental abnormality linking hypertension and insulin resistance [135].

These findings, both in platelets and in VSMC, support the hypothesis that a defect in the regulation of intracellular $\mathrm{Ca}^{2+}$ accompanies the reduction of insulin action and leads to an increase in vascular resistance, to arterial hypertension and to platelet hyperaggregability, features commonly observed in insulin-resistant states $[127,136-138]$.

\section{Insulin, cyclic nucleotides and NO in platelets: similarities with VSMC and alterations in the insulin- resistant states}

Some studies investigated in platelets the insulin effects on cAMP and cGMP, the main inhibitory systems of platelet activation. In other cell types, insulin reduces platelet levels of cAMP by inhibiting adenylate cyclase [139] and by stimulating cAMP phosphodiesterases [140-141]. In adipose cells, this mechanism accounts for the anti-lipolytic effect of the hormone [142]. On the other hand, both in adipose and in liver cells, insulin induces a prompt increase of cGMP (with a maximum effect at 2 and at $6 \mathrm{~min}$, respectively) [143]. Finally, in rats with streptozotocininduced diabetes mellitus, there is a decreased hepatic guanylate cyclase activity [144].

The first effect noted of insulin on cyclic nucleotides in platelets is an increase in the activity of phosphodiesterases [76, 145]: insulin activates, via a serine phosphorylation, the cGMP-inhibited cAMP 
phosphodiesterase, that represents more than $75 \%$ of cAMP phosphodiesterase activity in a platelet extract [145]. The biological meaning of this insulin action could be a reduction of cyclic nucleotides, and in particular of cAMP. This has never been observed in platelets, indicating that other biochemical events also modulate the insulin action on cyclic nucleotides in these cells.

Studies from our laboratory on platelet-rich plasma show that insulin increases platelet concentrations of cGMP [82]. This effect is mediated by the phosphorylation of the insulin receptor, being blunted by genistein, a tyrosine kinase inhibitor [82], and is completely blocked by methylene blue [82] and by L-NMMA [146]. These last observations induced us to speculate that insulin increases cGMP in platelets via NO [146]. Recent studies of our group demonstrated that insulin increases the synthesis of NO, measured by the ${ }^{3} \mathrm{H}$-arginine $/{ }^{3} \mathrm{H}$-citrulline method, in human platelets [147]. This is one of the very few studies demonstrating a direct insulin action on NO synthesis in human cells in vitro, and the first one in platelets. An insulin-induced increase of NO production has been demonstrated in endothelial cells [148].

The insulin action on cGMP in platelets shows a plateau between 2 and $20 \mathrm{~min}$, declines after $20 \mathrm{~min}$ but is still significant at $120 \mathrm{~min}$ [147]. The decline with time of the cGMP response to insulin is not surprising, since insulin increases cGMP via NO. Also pretreatment of tissues with nitro-vasodilators results in a molecular desensitization of soluble guanylate cyclase $[149,150]$, and the NO-induced activation of guanylate cyclase is reversible over time [151,152].

We also demonstrated that insulin increases platelet concentrations of cAMP in a very short time [147]. These results do not conflict with those of other authors who were unable to demonstrate an insulin effect on platelet cAMP after at least 120 min of incubation [87] because the insulin action on cAMP reaches a plateau between 2 and $20 \mathrm{~min}$, declines after $20 \mathrm{~min}$ and is no more significant at $60 \mathrm{~min}$ [147]. Interestingly, the insulin effect on cAMP is inhibited by methylene blue and by L-NMMA, demonstrating that it is a NO-mediated event [147]. This phenomenon is not surprising, since nitro-vasodilators, that are NO-donors, also enhance both cGMP and cAMP in platelets $[69,73,153]$. Actually, the increase of cGMP they induce blunts the cGMP-inhibited cAMP phosphodiesterase, thus decreasing cAMP catabolism and increasing cAMP concentrations [73]. Since insulin increases cGMP via NO, a similar phenomenon could take place after insulin incubation. In this case, insulin should be able to indirectly inhibit, through cGMP, the same cAMP phosphodiesterase that it activates per se [145].

Another possible interpretation of the insulin-induced increase of platelet cAMP derives from the observation that, when guanylate cyclase is stimulated by NO donors, it shows striking alterations in its properties, becoming able to synthesize not only cGMP but also cAMP [154]. A similar mechanism could explain the insulin-induced increase of cAMP, since insulin enhances NO in platelets [147] and stimulates platelet guanylate cyclase via NO.

Finally, we observed that a 8 min-insulin incubation enhances dose-dependently the effects on cAMP of substances able to activate adenylate cyclase with a receptor-dependent mechanism, such as Iloprost, a $\mathrm{PGI}_{2}$ analogue [37], or with a receptor-independent mechanism, such as forskolin [42] and that these effects are also NO-mediated, being blunted by L-NMMA [147]. As a consequence, insulin dose-dependently enhances the anti-aggregating effects of these substances [147]. Thus, insulin increases the influence on cAMP of adenylate-cyclase stimulating agents because it increases cAMP per se via a NO-mediated mechanism [147]. The ability of insulin to increase the anti-aggreating effects of $\mathrm{PGI}_{2}$ explains the very effective platelet modulating action exerted by the hormone in vivo [79, 81, 85], where $\mathrm{PGI}_{2}$ is released into the circulation by endothelial cells. $\mathrm{PGI}_{2}$ and $\mathrm{NO}$, in fact, act synergistically to reduce platelet aggregation [67-69], and insulin interplays with both of these physiological anti-aggregating substances by enhancing NO synthesis and, through $\mathrm{NO}$, by increasing $\mathrm{PGI}_{2}$ effects [147].

The relevance of cyclic nucleotides in the anti-aggregating effect exerted by insulin is further supported by the fact that insulin does not reduce platelet sensitivity to agonists in the presence of methylene blue, a substance able to inhibit both guanylate cyclase and NOS [82].

Data from our laboratory demonstrate that insulin increases both cGMP and cAMP through NO also in human VSMC, as in platelets, since its effects are blunted by L-NMMA [155-156]. Furthermore, in VSMC insulin enhances the effects on cAMP of adenylate cyclase activators, such as Iloprost [155], forskolin [155] and $\beta$-adrenergic agonists [156] with a mechanism mediated by NO, being inhibited by LNMMA [156]. Very recently, we observed that human VSMC show a NOS activity able to be stimulated within a few minutes by the $\mathrm{Ca}^{2+}$ ionophore ionomycin and by insulin and to induce, via NO, rapid increases of cyclic nucleotides [157]. Together with other recent evidence, these data support the contention that VSMC have not only an inducible, $\mathrm{Ca}^{2+}$-independent NOS, responsible for a delayed release of NO following activation by cytokines, but also a $\mathrm{Ca}^{2+}$-dependent NOS, that could be a constitutive isoform, able to be activated within a few minutes by insulin $[119,157]$. Thus, insulin-induced vasodilation could be attributed not only to the effects on VSMC of endothelium-derived NO but also to that exerted by insulin directly on VSMC. 

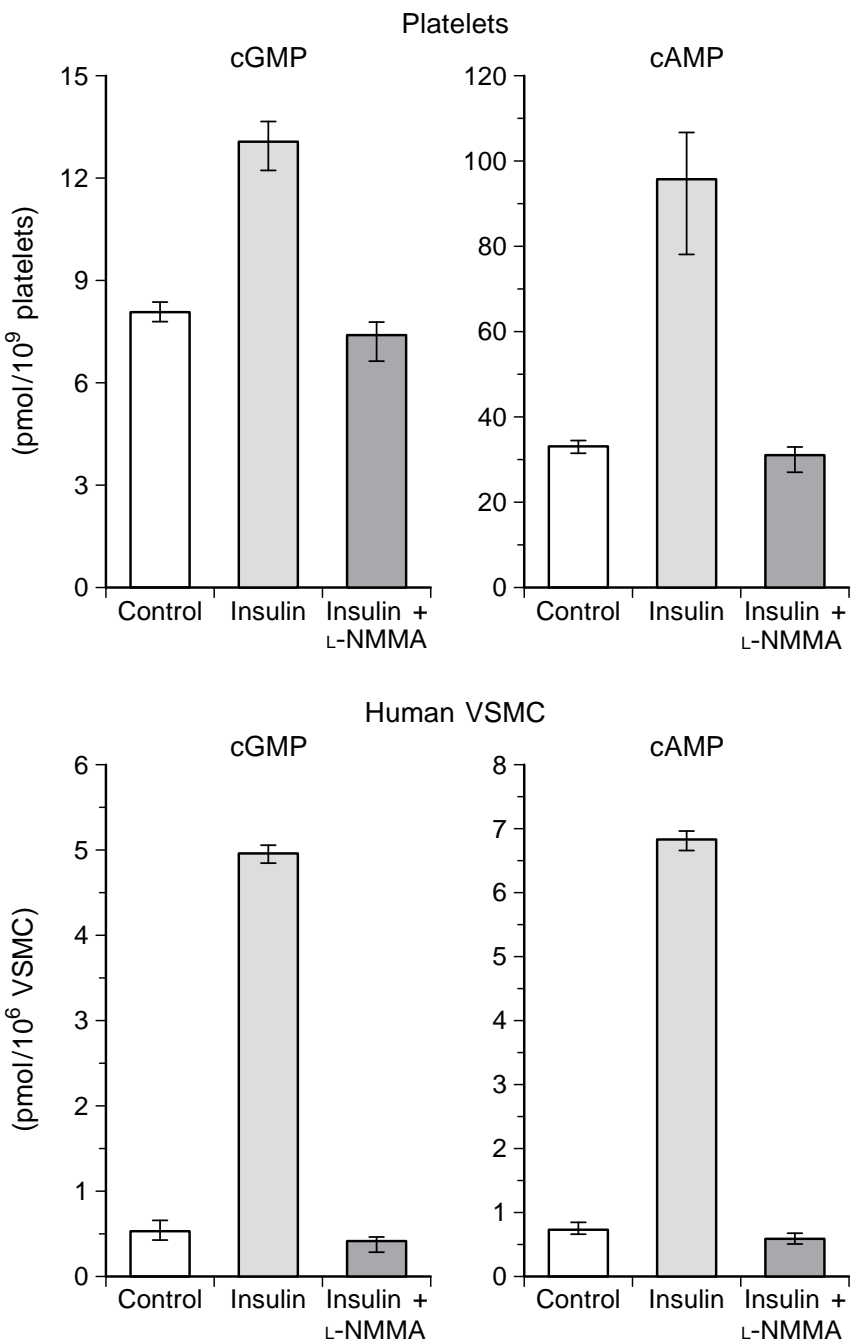

Fig.1. Insulin increases both cGMP and cAMP in platelets and in human VSMC via NO, its effects being completely blunted by the NO synthase inhibitor L-NMMA. cGMP and cAMP are the main inhibitory mediators of platelet activation and of VSMC constriction, being able to attenuate calcium fluxes. The ability of NO to increase not only cGMP but also cAMP is discussed in the text. In these experiments $(n=6)$, representative of many others carried out in our laboratory, the cells were incubated for $15 \mathrm{~min}$ with $2 \mathrm{nmol} / \mathrm{l}$ insulin, with and without a $20 \mathrm{~min}$ preincubation with L-NMMA (100 $\mu \mathrm{mol} / 1$ in platelets, $2 \mathrm{mmol} / \mathrm{l}$ in hVSMC), and the insulininduced increases of cGMP and cAMP were significant $(p=0.03-0.0001)$

Figure 1 shows the similarities in the NO-mediated insulin actions on cyclic nucleotides in platelets and in VSMC.

Further studies are needed to clarify the mechanisms by which insulin stimulates NOS activity in platelets and in VSMC. In platelets, insulin activates the cGMP-inhibited cAMP phosphodiesterase via a serine phosphorylation [145]. A putative insulin effect on NOS, which is to be proven experimentally, could be a serine phosphorylation, which would result in its activation [158].
In the insulin-resistant states of obesity and obese Type II diabetes mellitus, we observed that the ability of both insulin and the NO donor glyceryl-trinitrate (GTN) to increase cGMP and to reduce platelet activation is blunted [83, 159], whereas lean Type II diabetic patients show a normal cGMP response to both insulin and GTN [159]. Similarly, in platelets from patients affected by essential hypertension which is an insulin-resistant condition [93], the inhibition of platelet $\mathrm{Ca}^{2+}$ fluxes induced by another NO donor, sodium nitroprusside, is impaired [160]. Thus, insulin/NO and NO/cGMP pathways are altered in the insulin-resistant states.

In summary, insulin activates NOS activity, both in platelets and VSMC; via NO, it rapidly increases the intracellular content of both cGMP and cAMP and enhances the effects of cAMP-increasing substances; through cyclic nucleotides, it decreases intracellular $\mathrm{Ca}^{2+}$, and therefore reduces platelet activation and vasoconstriction. These insulin effects in platelets are blunted in the insulin-resistant subjects.

We have mentioned that a putative mechanism by which insulin reduces $\mathrm{Ca}^{2+}$ fluxes is the activation of $\mathrm{Na}^{+}-\mathrm{K}^{+}$ATPase [110-112]. This insulin effect could also be mediated by $\mathrm{NO}$, since it stimulates $\mathrm{Na}^{+}-\mathrm{K}^{+}$ ATPase activity $[161,162]$, a phenomenon accounting for the NO-induced depolarization of vascular smooth muscle [163]. Furthermore, NO directly activates $\mathrm{Ca}^{2+}$-dependent $\mathrm{K}^{+}$channels, which reduce $\mathrm{Ca}^{2+}$ influx through voltage-operated $\mathrm{Ca}^{2+}$ channels [164].

\section{Insulin and platelet binding of prostanoids and catecholamines}

Insulin up-regulates prostacyclin binding and downregulates $\alpha_{2}$-adrenergic receptors in human platelets, thus attenuating platelet responses. In particular, studies carried out by incubating platelet preparations with insulin for at least $2 \mathrm{~h}$ at $23^{\circ} \mathrm{C}$ demonstrated that the hormone increases $\mathrm{PGE}_{1}$ binding to platelets, and thereby enhances platelet sensitivity to the inhibitory effect of the prostanoid through the increased formation of cAMP [87]. The time course of the insulin effect on $\mathrm{PGE}_{1} / \mathrm{PGI}_{2}$ receptor number follows that of the insulin binding to platelets [87]. Further studies of the same research group confirmed that insulin interacts with the binding of $\mathrm{PGE}_{1} / \mathrm{PGI}_{2}$ with prostanoid receptors [165], by a mechanism involving G-proteins [166]. Insulin also amplifies the antiaggregatory effect of $\mathrm{PGE}_{1}$ in rat platelets [167].

Experiments carried out in vivo by an iv bolus injection of insulin followed by a $2.5 \mathrm{~h}$ insulin infusion, with plasma glucose kept constant by a simultaneous glucose infusion, demonstrated that insulin increases $\mathrm{PGE}_{1}$ and $\mathrm{PGI}_{2}$ binding to platelets by two- to threefold over control. This is due to an increase of both high and low affinity receptor number, with small 
changes in receptor affinity. This increased binding was associated with more than a twofold decrease in the minimum prostanoid concentrations needed to inhibit platelet aggregation through cAMP formation [86]. Other authors demonstrated that a 2-h insulin infusion during a euglycaemic insulin clamp results in a $65 \%$ increase of $\mathrm{PGE}_{1}$-stimulated cAMP concentrations [168]. Infusion of insulin in vivo without changing blood glucose concentrations not only increases prostanoid binding to platelets, but even enhances $\mathrm{PGI}_{2}$ in plasma, compatible with an increased synthesis by endothelial cells [86].

During acute spontaneous angina and acute ischaemic heart disease, platelet hyperactivation plays a pivotal role in vessel occlusion $[169,170]$. This phenomenon is in part due to a reduced platelet sensitivity to vasodilating prostanoids [171], owing to a reduction of their specific receptors [172, 173]. These alterations can be corrected by treating platelets with insulin: a 3-h incubation of platelets with the hormone, in effect, resulted in increased specific binding of $\mathrm{PGI}_{2}$ in $75 \%$ of patients with acute myocardial infarction or unstable angina [174]. This effect was due to an increase of both high- and low-affinity receptor number, without changes in affinity [174]. An increase in cAMP corresponded to the increase in binding [174]. These data suggest that giving insulin after an acute ischaemic event inhibits, at least in part, thrombus formation by the restoration of the prostanoid receptor activity. The same authors verified this intriguing hypothesis and found that giving insulin to patients with unstable angina pectoris or acute myocardial infarction returned to normal the impaired response of platelets to $\mathrm{PGE}_{1} / \mathrm{PGI}_{2}$ and the synthesis of $\mathrm{PGI}_{2}$ [175].

During acute ischaemic heart disease, there is also a transient decrease of insulin binding to platelets, which is related to changes in the sensitivity to $\mathrm{PGE}_{1}$ [176]. Thus, acute alterations in the insulin-platelet inter-relationships are involved in the prothrombotic state accompanying acute vascular events. Similarly, in subjects with chronic spinal cord injury, in whom coronary artery disease is a leading cause of death, $\mathrm{PGI}_{2}$ fails to inhibit the platelet-stimulated thrombin generation owing to the loss of high-affinity receptor sites for the prostanoid [177]. These platelet defects are corrected with platelet treatment with insulin [177]

Thus, these studies support the conclusion that insulin interplays with prostanoid effects on platelets not only by enhancing within a few minutes the increase of cAMP they induce via its own, NO-mediated, effect on cAMP [147] but also by enhancing prostanoid binding to platelets after $2 \mathrm{~h}$.

In vitro studies also demonstrated that incubation of human platelets with insulin for $2.5 \mathrm{~h}$ at $23^{\circ} \mathrm{C}$ increases their resistance to adrenaline aggregating effects and inhibits the potentiating effect of adrenaline on ADP-induced aggregation [88]. These phenomena have been attributed to a decrease by insulin of the number of $\alpha_{2}$-adrenergic receptors that account for the aggregating response to adrenaline [88]. A possible explanation for the insulin-induced up-regulation of prostanoid receptors and down-regulation of $\alpha_{2}$ adrenergic receptors is an insulin influence on cell membrane properties [178].

In summary, when platelets are exposed to insulin for a period of 120-150 $\mathrm{min}$, both in vivo and in vitro, they show an up-regulation of prostanoid receptors and a down-regulation of $\alpha_{2}$-adrenergic receptors resulting in anti-aggregation. Furthermore, platelet binding to anti-aggregating prostanoids is impaired during acute cardiovascular events and restored by insulin.

\section{Insulin and magnesium fluxes in platelets}

Insulin dose- and time-dependently increases platelet uptake of $\mathrm{Mg}^{2+}$ from the extracellular space with a maximal effect achieved by incubation with $200 \mu \mathrm{U} /$ $\mathrm{ml}$ insulin for $30 \mathrm{~min}$ [179]. This effect is mediated by insulin receptors being blunted in the presence of an anti-insulin receptor monoclonal antibody [179]. The insulin effects on $\mathrm{Ca}^{2+}$ and $\mathrm{Mg}^{2+}$ could be inter-related since decreases in $\mathrm{Mg}^{2+}$ concentrations lead to an increase in intracellular $\mathrm{Ca}^{2+}$ and to enhancement of platelet aggregation [180]. Insulin resistance states are characterized by decreased intracellular $\mathrm{Mg}^{2+}$ and increased intracellular $\mathrm{Ca}^{2+}[127$, 181]. This fact could be attributed to lack of physiological insulin action on $\mathrm{Mg}^{2+}$ and $\mathrm{Ca}^{2+}$ handling.

\section{Insulin and platelet-mediated modulation of fibrinolysis}

Platelets modulate fibrinolysis since they show both anti-fibrinolytic and pro-fibrinolytic activities, containing both plasminogen activator inhibitor I (PAII) [182] and plasminogen activators [183, 184].

It has been demonstrated that: i) incubation of washed platelets with insulin $(200 \mu \mathrm{U} / \mathrm{ml})$ at $37^{\circ} \mathrm{C}$ for $3 \mathrm{~h}$ results in a 3 -fold increase in plasminogen activator activity in the supernatant; ii) treatment of plasma membranes with insulin also enhances the release of platelet plasminogen activator, a phenomenon completely blunted by agents able to increase platelet cAMP [185]. Since platelets do not synthesize proteins, this insulin effect could be ascribed to enzyme activation or its release from platelet membrane or both. The insulin action on platelets, therefore, could account for an increase of the fibrinolytic activity suggesting that both insulin deficiency and insulin resistance can increase the incidence of thrombosis in diabetic patients. 
Interestingly, in Type II diabetic patients, fasting plasma insulin is correlated with platelet PAI-1, demonstrating an influence of insulin per se, or of insulin resistance, in platelet anti-fibrinolytic activity [186]. In VSMC, insulin stimulates PAI-1 secretion and gene expression [187].

\section{Conclusion}

Platelets, as VSMC, are targets of insulin action and subject to changes in insulin sensitivity. The main insulin effect in these cells is to inhibit $\mathrm{Ca}^{2+}$ fluxes, especially those from internal stores to cytosol, with a consequent reduction of agonist-stimulated platelet aggregation and vessel contraction.

The insulin effects on $\mathrm{Ca}^{2+}$ fluxes are regulated in both cell types by the cyclic nucleotides cGMP and cAMP, that insulin increases via NO, which thus becomes the key to understanding insulin action on platelet and VSMC function. Even if the insulin-induced vasodilation occurring in vivo is mainly attributable to the influence on VSMC of endothelium-derived NO, insulin also exerts direct effects on these cells. Furthermore, both in platelets and in VSMC, insulin increases via NO the influence on cAMP of other anti-aggregating and vasodilating substances (i.e. prostacyclin and $\beta$-adrenergic agonists), thereby enhancing their biological effect.

Finally, insulin increases platelet binding of antiaggregating prostanoids, and decreases platelet binding of $\alpha_{2}$-adrenergic agonists, with a final anti-aggregating effect.

In the insulin-resistant states, insulin effects on platelet cyclic nucleotides are attenuated, and the insulin-dependent reduction of $\mathrm{Ca}^{2+}$ fluxes is impaired both in platelets and in VSMC. These changes might explain why the insulin resistance syndrome is characterized by an altered intracellular ionic milieu, by an enhanced platelet activation and by a great prevalence of arterial hypertension, which can account for the increased vascular risk [93].

However, the described vasoprotective effects exerted by insulin on platelets and VSMC are only some of the many aspects of the influence of insulin on factors involved in atherogenesis and arterial hypertension: we should also remember the stimulatory role exerted by insulin on VSMC proliferation [188, $189]$, and on the sympathetic tone and sodium reabsorption [93].

Finally, this review offers some elements to better understand the role of insulin deficiency and of insulin resistance in determining the platelet alterations described in diabetes mellitus, which play a major role in the pathogenesis of diabetic angiopathy [190].

\section{References}

1. Savage PJ, Saad MF (1993) Insulin and atherosclerosis: villain, accomplice, or innocent bystander? Br Heart J 69: 473-475

2. Jarrett RJ (1994) Why insulin is not a risk factor for coronary heart disease? Diabetologia 37: 945-947

3. Fontbonne A (1994) Why can insulin levels indicate a risk for coronary heart disease? Diabetologia 37: 953-955

4. Stern MP (1994) The insulin-resistance syndrome: the controversy is dead, long live the controversy! Diabetologia 37: 956-958

5. Stout RW, Valliance-Owen W (1969) Insulin and atheroma. Lancet 2: 1078-1080

6. Ross R (1986) The pathogenesis of atherosclerosis - an update. N Engl J Med 314: 488-500

7. Niederman R, Pollard TD (1975) Human platelet myosin. II. In vitro assembly and structure of myosin filaments. J Cell Biol 67: 72-92

8. Colwell JA, Winocour PD, Lopes-Virella MF (1989) Platelet function and platelet-plasma interactions in atherosclerosis and diabetes mellitus. In: Rifkin H, Porte D (eds) Diabetes Mellitus: theory and practice. Elsevier, New York, pp 249-256

9. Kroll MH, Schafer AI (1989) Biochemical mechanisms of platelet activation. Blood 74: 1181-1195

10. Siess W (1989) Molecular mechanisms of platelet activation. Physiol Rev 69 (1): 48-178

11. Ware AJ, Coller BS (1995) Platelet morphology, biochemistry and function. In: Beutler E, Lichtman MA, Coller BS, Kipps TJ (eds) Williams Hematology. McGraw-Hill Inc, New York, pp 1161-1201

12. Anfossi G, Trovati M (1996) Role of catecholamines in platelet function: pathophysiological and clinical significance. Eur J Clin Invest 26: 353-370

13. Ardlie NG (1982) Calcium ions, drug action, and platelet function. Pharmacol Ther 18: 249-270

14. Brune B, Ullrich V (1991) Different calcium pools in human platelets and their role in thromboxane $\mathrm{A}_{2}$ formation. J Biol Chem 266: 19232-19237

15. Brune B, von Appen F, Ullrich V (1994) Receptor occupancy regulates $\mathrm{Ca}^{2+}$ entry and intracellular $\mathrm{Ca}^{2+}$ redistribution in activated human platelets. Biochem J 304: 993-999

16. Standley PR, Gangasani S, Prakash R, Sowers JR (1991) Human platelet calcium measurements: methodological considerations and comparisons with calcium mobilization in vascular smooth muscle cells. Am J Hypertens 4: $546-549$

17. Somlyo AP, Somlyo AV (1994) Signal transduction regulation in smooth muscle. Nature (Lond) 372: 231-236

18. El-Daher SS, Eigenthaler M, Walter U et al. (1996) Distribution and activation of cAMP- and cGMP-dependent protein kinases in highly purified human platelet plasma and intracellular membranes. Thromb Haemost 76: 1063-1071

19. Lerea KM, Glomset JA (1987) Agents that elevate the concentrations of cAMP in platelets inhibit the formation of $\mathrm{NaDodSO}_{4}$-resistant complex between thrombin and $40-\mathrm{kDa}$ protein. Proc Natl Acad Sci USA 84: $5620-5624$

20. Watson SP, McConnell RT, Lapetina E (1984) The rapid formation of inositol phosphates in human platelets by thrombin is inhibited by prostacyclin. J Biol Chem 259: 13199-13203

21. Doni MG, Deana R, Bertoncello S, Zoccarato F, Alexandre A (1988) Forskolin and prostacyclin inhibit fluoride- 
induced platelet activation and protein kinase C-dependent responses. Biochem Biophys Res Commun 156: $1316-1323$

22. Johansson JS, Nied LE, Haynes DH (1992) Cyclic AMP stimulates $\mathrm{Ca}^{2+}$-ATPase-mediated $\mathrm{Ca}^{2+}$ extrusion from human platelets. Biochim Biophys Acta 1105: 19-28

23. Tao J, Johansson JS, Haynes DH (1992) Stimulation of dense tubular $\mathrm{Ca}^{2+}$ uptake in human platelets by cAMP. Biochim Biophys Acta 1105: 29-39

24. Geiger J, Nolte C, Butt E, Sage SO, Walter U (1992) Role of cGMP and cGMP-dependent protein kinase in nitrovasodilator inhibition of agonist-evoked calcium elevation in human platelets. Proc Natl Acad Sci USA 89: 1031-1035

25. Deana R, Ruzzene M, Doni MG, Zoccorato F, Alexandre A (1989) Cyclic GMP and nitroprusside inhibit activation of human platelets by fluoroaluminate. Biochim Biophys Acta 1014: 203-206

26. Doni MG, Deana R, Padoin E, Ruzzene M, Alexandre A (1991) Platelet activation by diacylglycerol or ionomycin is inhibited by nitroprusside. Biochim Biophys Acta 1094: 323-329

27. Cavallini L, Coassin MG, Borean A, Alexandre A (1996) Prostacyclin and sodium nitroprusside inhibit the activity of the platelet inositol 1,4,5-trisphosphate receptor and promote its phosphorylation. J Biol Chem 8: 5545-5551

28. Doni MG, Cavallini L, Alexandre A (1994) $\mathrm{Ca}^{2+}$ influx in platelets: activation by thrombin and by the depletion of stores. Effect of cyclic nucleotides. Biochem J (1994) 303: 599-605

29. Kimura M, Kasker N, Aviv A (1982) Cyclic nucleotides attenuate thrombin-evoked alterations in parameters of platelet $\mathrm{Na} / \mathrm{H}$ antiport. The role of cytosolic $\mathrm{pH}$. J Clin Invest 89 : $1121-1127$

30. Nakashima Y, Tohmatsu T, Hattori H, Okano Y, Nozawa Y (1986) Inhibitory action of cyclic GMP on secretion, polyphosphoinositide hydrolysis and calcium mobilization in thrombin stimulated human platelets. Biochem Biophys Res Commun 135: 1099-1104

31. Siess W, Grunberg B, Luber K (1993) Functional relationship between cyclic AMP-dependent protein phosphorylation and platelet inhibition. Adv Exp Med Biol 344: 299-335

32. Ignarro LJ, Kadowitz PJ (1985) Pharmacological and physiological role of cGMP in vascular smooth muscle cell relaxation. Annu Rev Pharmacol Toxicol 25: 171-191

33. Ishikawa T, Hume JR, Keef KD (1993) Regulation of $\mathrm{Ca}^{2+}$ channels by cAMP and cGMP in vascular smooth muscle cells. Circ Res 73: 1128-1137

34. Yamagishi T, Yanagisawa T, Satoh K, Taira N (1994) Relaxant mechanisms of cyclic AMP-increasing agents in porcine coronary artery. Eur J Pharmacol 251: 253-262

35. Murad F (1996) Cyclic guanosine monophosphate as a mediator of vasodilation. J Clin Invest 78: 1-5

36. Gorman RR, Bunting S, Miller OV (1977) Modulation of human platelet adenylate cyclase by prostacyclin. Prostaglandins 13: 377-388

37. Tateson J, Moncada S, Vane JR (1977) Effects of prostacyclin on cyclic AMP concentrations in human platelets. Prostaglandins 13: 389-399

38. Dutta-Roy AK, Sinha AK (1987) Purification and properties of prostaglandin $E_{1} /$ prostacyclin receptor of human blood platelets. J Biol Chem 262: 12685-12691

39. Van Calker P, Muller M, Hamprecht B (1979) Adenosine regulates via two different types of receptors the accumulation of cAMP in cultured brain cells. J Neurochem 33: 999-1005
40. Kerry K, Scrutton MC (1983) Platelet $\beta$-receptors. Br J Pharmacol 79: 681-691

41. Sibley DR, Monsma FJ (1992) Molecular biology of dopamine receptors. Trends Pharmacol Sci 13: 61-69

42. Seamon KB, Daly JW (1983) Forskolin, cyclic AMP and cellular physiology. Trend Pharmacol Sci 4: 120-132

43. Simonds WF, Goldsmith PK, Codina J (1982) $\mathrm{Gi}_{2}$ mediates $\alpha_{2}$-adrenergic inhibition of adenylyl cyclase in platelet membranes: in situ identification with $\mathrm{G} \alpha \mathrm{C}$-terminal antibodies. Proc Natl Acad Sci USA 86: 7809-7813

44. Moncada S, Vane JR (1979) Pharmacology and endogenous roles of prostaglandin endoperoxides, thromboxane $\mathrm{A}_{2}$ and prostacyclin. Pharmacol Rev 30: 293-331

45. Mustard JF, Kinlough-Rathbone RJ, Packham MA (1987) Vessel wall and thrombosis. In: Colman RW, Hirsch J, Marder VJ, Salzman E (eds) Hemostasis and Thrombosis. JB Lippincott Co, Philadelphia, pp 1073-1088

46. Waldman SA, Murad F (1987) Cyclic GMP synthesis and function. Pharmacol Rev 39: 163-196

47. Palmer RMJ, Ashton DS, Moncada S (1988) Vascular endothelial cells synthesize nitric oxide from L-arginine. $\mathrm{Na}$ ture 333: 664-666

48. Palmer RMJ, Ferridge AG, Moncada S (1987) Nitric oxide release accounts for the biological activity of endothelium-derived relaxing factor. Nature (Lond) 327: 524-526

49. Mellion BT, Ignarro LJ, Ohlstein EH, Pontecorvo EG, Hyman AL, Kadowitz PJ (1981) Evidence for the inhibitory role of guanosine- $3{ }^{\prime}, 5^{\prime}$-cyclic monophosphate in ADP-induced human platelet aggregation in the presence of nitric oxide and related vasodilators. Blood 57: 946-955

50. Moncada S, Palmer RMJ, Higgs EA (1991) Nitric oxide: physiology, pathophysiology, and pharmacology. Pharmacol Rev 43: 109-141

51. de Graaf JC, Banga JD, Moncada S, Palmer RMJ, de Groot PG, Sixma JJ (1992) Nitric oxide functions as an inhibitor of platelet adhesion under flow conditions. Circulation 85: 2284-2290

52. Stamler J, Mendelsohn ME, Amarante P,et al. (1989) NAcetylcysteine potentiates platelet inhibition by endothelium-derived relaxing factor. Circ Res 65: 789-795

53. Michelson AD, Benoit SE, Furman MI, et al. (1996) Effects of endothelium-derived relaxing factor/nitric oxide on platelet surface glycoproteins. Am J Physiol 270:H1640-H1648

54. Bredt DS, Snyder SH (1990) Isolation of nitric oxide synthase, a calmodulin-requiring enzyme. Proc Natl Acad Sci USA 87: 682-685

55. Radomski MW, Palmer RMJ, Moncada S (1990) An Larginine/nitric oxide pathway present in human platelets regulates aggregation. Proc Natl Acad Sci USA 87: 5193-5197

56. Radomski MW, Palmer RMJ, Moncada S (1990) Characterization of the L-arginine: nitric oxide pathway in human platelets. Br J Pharmacol 101: 325-328

57. Sase K, Michel T (1995) Expression of constitutive endothelial nitric oxide synthase in human blood platelets. Life Sci 57: 2049-2055

58. Chen LY, Metha JL (1996) Variable effects of L-arginine analogs on L-arginine-nitric oxide pathway in human neutrophils and platelets may relate to different nitric oxide synthase isoforms. J Pharmacol Exp Ther 276: 253-257

59. Muragandam A, Mutus B (1994) Isolation of nitric oxide synthase from human platelets. Biochim Biophys Acta 1200: $1-6$

60. Malinski T, Radomski MW, Taha Z, Moncada S (1993) Direct electrochemical measurement of nitric oxide re- 
leased from human platelets. Biochem Biophys Res Commun 194: 960-965

61. Zhou Q, Hellermann GR, Solomonson LP (1995) Nitric oxide release from resting human platelets. Thromb Res 77: 87-96

62. Freedman JE, Loscalzo J, Barnard MR, Alpert C, Keaney JF Jr, Michelson AD (1997) Nitric oxide released from activated platelets inhibits platelet recruitment. J Clin Invest 100: 350-356

63. Palmer RMJ, Rees DD, Ashton DS, Moncada S (1988) LArginine is the physiological precursor for the formation of nitric oxide in endothelium-dependent relaxation. Biochem Biophys Res Commun 153: 1251-1256

64. Griscavage JM, Fukuto JM, Komori Y, Ignarro LJ (1994) Nitric oxide inhibits neuronal nitric oxide synthase by interacting with the heme prosthetic group. J Biol Chem 269: 21644-21649

65. Bodzenta-Lukaszyke A, Gbryelewicz A, Lukaszyk A, Bielawiec M, Konturek JW, Domschke W (1994) Nitric oxide synthase inhibition and platelet function. Thromb Res 75: 667-672

66. Adams MR, Forsyth CJ, Jessup W, Robinson J, Celermajer DS (1995) Oral L-arginine inhibits platelet aggregation but does not enhance endothelium-dependent dilation in healthy young man. J Am Coll Cardiol 26: 1054-1061

67. Radomski MW, Palmer RMJ, Moncada S (1987) The antiaggregating properties of vascular endothelium: interactions between prostacyclin and nitric oxide. Br J Pharmacol 92: 639-646

68. Macdonald PS, Read MA, Dusting GJ (1988) Synergistic inhibition of platelet aggregation by endothelium-derived relaxing factor and prostacyclin. Thromb Res 49: 437-449

69. Anfossi G, Massucco P, Mularoni E, Cavalot F, Mattiello L, Trovati M (1993) Organic nitrates and compounds that increase intraplatelet cyclic guanosine monophosphate (cGMP) levels enhance the antiaggregating effects of the stable prostacyclin analogue Iloprost. Prostaglandins Leukot Essent Fatty Acids 49: 839-845

70. Salvemini D, Currie MG, Mollace V (1996) Nitric oxidemediated cyclooxygenase activation: a key event in the antiplatelet effects of nitrovasodilators. J Clin Invest 97: 2562-2568

71. Sheth S, Colman R (1995) Regulatory and catalytic domains of platelet cAMP phosphodiesterases: targets for drug design. Semin Hematol 31: 110-119

72. Conti M, Nemoz G, Sette C, Vicini E (1995) Recent progress in understanding the hormonal regulation of phosphodiesterases. Endocr Rev 16: 370-389

73. Maurice DH, Haslam RJ (1990) Molecular basis of the synergistic inhibition of platelet function by nitrovasodilators and activators of adenylate cyclase: inhibition of cyclic AMP breakdown by cyclic GMP. Mol Pharmacol 37: 671-681

74. Hajek A, Joist J, Baker RK, Jarrett L (1979) Demonstration and partial characterization of insulin receptors in human platelets. J Clin Invest 63: 1060-1065

75. Falcon C, Pfliegler G, Deckmyn H, Vermylen J (1988) The platelet insulin receptor: detection, partial characterization, and search for a function. Biochem Biophys Res Commun 157: 1190-1196

76. Lopez Aparicio P, Rascona A, Manganiello VC, Andersson KE, Belfrage P, Degerman E (1992) Insulin-induced phosphorylation and activation of cGMP-inhibited cAMP phosphodiesterase in human platelets. Biochem Biophys Res Commun 186: 517-523
77. Udvardy G, Pfliegler G, Rab K (1985) Platelet insulin receptor determination in non-insulin dependent diabetes mellitus. Experientia 41: 422-423

78. Trovati M, Anfossi G, Cavalot F, et al. (1986) Studies on mechanisms involved in hypoglycemia-induced platelet activation. Diabetes 35: 818-825

79. Trovati M, Anfossi G, Cavalot F, Massucco P, Mularoni E, Emanuelli G (1988) Insulin directly reduces platelet sensitivity to aggregating agents. Studies in vitro and in vivo. Diabetes 37: 780-786

80. Trovati M, Anfossi G, Mularoni E, Massucco P, Bosia A, Emanuelli G (1989) Insulin reduces platelet sensitivity to platelet activating factor in washed human platelets resuspended in a calcium-free medium. Diabetes, Nutrition \& Metabolism 2: 151-153

81. Trovati M, Anfossi G, Cavalot F, Massucco P, Mularoni E, Emanuelli G (1990) Physiological insulin concentrations reduce platelet sensitivity to adrenaline in vivo. In: Belfiore F, Molinatti GM, Reaven GM (eds) Tissue-specific metabolic alterations in diabetes. Frontiers in diabetes, vol 10. Karger, Basel, pp 166-169

82. Trovati M, Massucco P, Mattiello L, Mularoni E, Cavalot F, Anfossi G (1994) Insulin increases guanosine-3 ', 5 '-cyclic monophosphate in human platelets: a mechanism involved in the insulin anti-aggregating effect. Diabetes 43: 1015-1019

83. Trovati M, Mularoni E, Burzacca S et al. (1995) Impaired insulin-induced platelet anti-aggregating effect in obesity and in obese non-insulin-dependent diabetes mellitus. Diabetes 44: 1318-1322

84. Touyz RM, Schiffrin EL (1994) Blunted inhibition by insulin of agonist-stimulated calcium, $\mathrm{pH}$ and aggregatory responses in platelets from hypertensive patients. $\mathbf{J}$ Hypertens 12: 1255-1263

85. Hiramatsu K, Nozaki H, Arimori A (1987) Reduction of platelet aggregation induced by euglycaemic insulin clamp. Diabetologia 30: 310-313

86. Kahn NN, Bauman WA, Sinha AK (1993) Inhibition of platelet aggregation and the stimulation of prostacyclin synthesis by insulin in humans. Am J Physiol 265: H2160-H2167

87. Kahn NN, Sinha AK (1990) Stimulation of prostaglandin $\mathrm{E}_{1}$ binding to human blood platelet membrane by insulin and the activation of adenylate cyclase. J Biol Chem 265: 4976-4981

88. Kahn NN, Sinha AK (1992) Down regulation of $\alpha_{2}$ adrenergic receptor numbers in platelets by insulin. Biochim Biophys Acta 1134: 292-296

89. Dutta-Roy AK (1994) Insulin-mediated processes in platelets, erythrocytes and monocytes/macrophages: effects of essential fatty acid metabolism. Prostaglandins, Leukot Essent Fatty Acids 51: 385-399

90. Murer EH, Gyda MA, Martinez NJ (1994) Insulin increases the aggregation response of human platelets to ADP. Thromb Res 73: 69-74

91. Anfossi G, Massucco P, Mattiello L, et al. (1996) Insulin exerts opposite effects on platelet function at physiological and supraphysiological concentrations. Thromb Res 82: $57-68$

92. Reaven GM (1988) Role of insulin resistance in human disease. Diabetes 37: 1595-1607

93. De Fronzo RA, Ferrannini E (1991) Insulin resistance: a multifaceted syndrome responsible for NIDDM, obesity, hypertension, dyslipidemia, and atherosclerotic cardiovascular disease. Diabetes Care 14: 173-194

94. Standley PR, Zhang F, Ram JL, Zemel MB, Sowers JR (1991) Insulin attenuates vasopressin-induced calcium 
transients and voltage-dependent calcium current (a voltage-dependent calcium response) in rat vascular smooth muscle cells. J Clin Invest 88: 1230-1236

95. Wambach GK, Liu K (1992) Insulin attenuates vasoconstriction by noradrenaline, serotonin and potassium chloride in rat mesenteric arterioles. Clin Exp Hypertens A14: 733-740

96. Hori MT, Fittingoff M, Tuck ML (1992) Mechanism of insulin attenuation of calcium mobilization in cultured vascular smooth muscle cells. Hypertension 20: 397-398

97. Kuriyama S, Nakamura K, Horiguchi M, Uchida H, Sakai O (1992) Decreased insulin-sensitive $\mathrm{Ca}^{2+}$ transport in cultured vascular smooth muscle cells from spontaneously hypertensive rats. Am J Hypertens 5: 892-895

98. Standley PR, Ram JL, Sowers JR (1993) Insulin attenuation of vascular smooth muscle calcium responses in Zucker lean and obese rats. Endocrinology 133: 1693-1699

99. Kahn AM, Seidel CL, Allen JC, O'Neil RG, Shelat H, Song T (1993) Insulin reduces contractions and intracellular calcium concentration in vascular smooth muscle. Hypertension 22: 735-742

100. Kim YC, Zemel MB (1993) Insulin increases vascular smooth muscle recovery from intracellular calcium loads. Hypertension 22: 74-77

101. Ram JL, Fares MA, Standley PR, Sowers JR (1993) Insulin inhibits vasopressin-elicited contraction of vascular smooth muscle cells. Journal of Vascular Medicine and Biology 4: 250-255

102. Saito F, Hori MT, Fittingoff M, Hino T, Tuck ML (1993) Insulin attenuates agonist-mediated calcium mobilization in cultured rat vascular smooth muscle cells. J Clin Invest 92: $1161-1167$

103. Touyz RM, Tolloczko B, Schiffrin EL (1994) Insulin attenuates agonist-evoked calcium transients in vascular smooth muscle cells. Hypertension 23 [Suppl. I] I:23-28

104. Kahn AM, Allen JC, Seidel CL, Song T (1994) Insulin inhibits serotonin-induced $\mathrm{Ca}^{2+}$ influx in vascular smooth muscle. Circulation 90: 384-390

105. Inishi Y, Okuda T, Arakawa T, Kurokawa K (1994) Insulin attenuates intracellular calcium responses and cell contraction caused by vasoactive agents. Kidney Int 45: 1318-1325

106. Han SZ, Ouchi Y, Karaki H,Orimo H (1995) Inhibitory effects of insulin on cytosolic $\mathrm{Ca}^{2+}$ level and contraction in the rat aorta: endothelium - dependent and independent mechanisms. Circ. Res. 77: 673-678

107. Dick GM, Sturek M (1996) Effects of a physiological insulin concentration on the endothelin-sensitive $\mathrm{Ca}^{2+}$ store in porcine coronary artery smooth muscle. Diabetes 46 : 876-880

108. Somlyo AV, Bond M, Somlyo AP, Scarpa A (1985) Inositol trisphosphate-induced calcium release and contraction in vascular smooth muscle. Proc Natl Acad Sci USA 82: 5231-5235

109. Chadwick CC, Saito A, Fleischer S (1990) Isolation and characterization of the inositoltrisphosphate receptor from smooth muscle. Proc Natl Acad Sci USA 87: 2132-2136

110. Tirupattur PR, Ram JL, Standley PR, Sowers JR (1993) Regulation of $\mathrm{Na}^{+}-\mathrm{K}^{+}$-ATPase gene expression by insulin in vascular smooth muscle cells. Am J Hypertens 6: 626-629

111. Kahn AM, Song T (1995) Insulin inhibits dog vascular smooth muscle contraction and lowers $\mathrm{Ca}^{2}+\mathrm{i}$ by inhibiting $\mathrm{Ca}^{2+}$ influx. J Nutr 125: 1732S-1737S

112. Sowers JR (1996) Effects of insulin and IGF-1 on vascular smooth muscle glucose and cation metabolism. Diabetes 45: 47-51
113. Reuter H (1991) Sodium-calcium exchange : ins and outs of $\mathrm{Ca}^{2+}$ transport. Nature 349: 567-568

114. Moore RD (1983) Effects of insulin upon ion transport. Biochim Biophys Acta 737: 1-49

115. Ewart HS, Klip A (1995) Hormonal regulation of the $\mathrm{Na}^{+}-\mathrm{K}^{+}$-ATPase: mechanisms underlying rapid and sustained changes in pump activity. Am J Physiol 269: C295-C311

116. Ferrannini E, Taddei S, Santoro D et al. (1988) Independent stimulation of glucose metabolism and $\mathrm{Na}^{+}-\mathrm{K}^{+}$exchange by insulin in the human forearm. Am J Physiol 255:E953-E958

117. Ishida T, Matsuura $\mathrm{H}$, Ishida-Kainouchi $\mathrm{M}$ (1993) $\mathrm{Na}^{+}-$ $\mathrm{Ca}^{+}$exchange modulates $\mathrm{Ca}^{2+}$ handling of human platelets by altering intracellular $\mathrm{Ca}^{2+}$ store size. J Hypertens 11: 1089-1095

118. Chan A, Shinde R, Chow CC, Cockram SS, Swaminathan $\mathrm{R}$ (1994) Hyperinsulinaemia and $\mathrm{Na}^{+}, \mathrm{K}^{+}$-ATPase in thyrotoxic periodic paralysis. Clin Endocrinol (Oxf) 41: 213-216

119. Sowers JR (1997) Insulin and insulin-like growth factor in normal and pathological cardiovascular physiology. Hypertension 29: 691-699

120. Erne P, Bolli P, Burgisser E, Buhler ER (1984) Correlation of platelet calcium with blood pressure. Effects of anti-hypertensive therapy. N Engl J Med 310: 1084-1088

121. Buhler FR, Resink TJ (1988) Platelet membrane and calcium control abnormalities in essential hypertension. Am J Hypertens 1: 42-46

122. Oshima T, Young EW, Bukoski RD, McCarron DA (1990) Abnormal calcium handling by platelets of spontaneously hypertensive rats. Hypertension 15: 606-611

123. Oshima T, Young EW, Bukolski RD, McCarron DA (1991) Rise and fall of agonist-evoked platelet $\mathrm{Ca}^{2+}$ in hypertensive rats. Hypertension 18: 758-762

124. Ishii H, Nmeda F, Hashimoto T, Nawata H (1991) Increased intracellular calcium mobilization in platelets from pateints with type II (non-insulin-dependent) diabetes mellitus. Diabetologia 34: 332-336

125. Ishida-Kainouchi M, Matsuura H, Ishida T, Kajiyama G, Oshima T (1993) Platelet calcium handling in spontaneously hypertensive rats and in three strains of normotensive rats. J Hypertens 11: 509-514

126. Standley PR, Ali S, Bapna C, Sowers JR (1993) Increased platelet cytosolic calcium responses to low density lipoprotein in type II diabetes with and without hypertension. Am J Hypertens 6: 938-943

127. Levy J, Gavin JR, Sowers JR (1994) Diabetes mellitus: a disease of abnormal cellular calcium metabolism? Am J Med 96: 260-273

128. Takaya J, Iwamoto Y, Higashino H, Kino M, Kobayashi T, Kobayashi Y (1997) Altered intracellular calcium and phorbol 12,13-dibutyrate binding to intact platelets in young obese subjects. J Lab Clin Med 129: 245-250

129. Touyz RM, Schiffrin EL (1995) Treatment of non-insulindependent hypertensive patients with $\mathrm{Ca}^{2+}$ channel blockers is associated with increased platelet sensitivity to insulin. Am J Hypertens 8: 1214-1221

130. Baldi S, Natali A, Buzzigoli G, Galvan AQ, Sironi AM, Ferrannini E (1996) In vitro effect of insulin on intracellular calcium concentrations: relation to insulin resistance. Metabolism 45: 1402-1407

131. Touyz RM, Schiffrin EL (1994) Insulin-induced $\mathrm{Ca}^{2+}$ is altered in vascular smooth muscle cells of SHR. Hypertension 23: 931-935

132. Sowers JR, Standley PR, Ram JL, Jacober S (1993) Hyperinsulinemia, insulin resistance, and hyperglyce- 
mia: contributing factors in the pathogenesis of hypertension and atherosclerosis. Am J Hypertens 6: 260S-270S

133. Standley PR, Bakir MH, Sowers JR (1993) Vascular insulin abnormalities, hypertension and accelerated atherosclerosis. Am J Kidney Dis 21: 39-46

134. Epstein M, Sowers JR (1992) Diabetes mellitus and hypertension. Hypertension 19: 403-418

135. Ram JL, Standley PR, Sowers JR (1993) Hypertension, insulin function, and calcium. In: Draznin B, Eckel RH (eds) Diabetes and Atherosclerosis: molecular basis and clinical aspects. Elsevier, New York, pp 291-305

136. Draznin B, Sussman KE, Eckel RH, et al. (1988) Possible role of cytosolic free calcium concentrations in mediating insulin resistance of obesity and hyperinsulinemia. J Clin Invest 28: 1848-1852

137. Levy J, Zemel MB, Sowers JR (1989) Role of cellular calcium metabolism in abnormal glucose metabolism and diabetic hypertension. Am J Med 87 (suppl 6A):7S-16S

138. Resnick LM, Gupta RK, Bhargava KK et al. (1991) Cellular ions in hypertension, diabetes and obesity. A nuclear magnetic resonance spectroscopic study. Hypertension 17: 951-957

139. Illiano G, Cuatrecasas P (1972) Modulation of adenylate cyclase activity in liver and fat cell membranes by insulin. Science 1975: 906-908

140. Senft G, Schultz G, Munske K, Hoffman M (1968) Influence of insulin on cyclic $3^{\prime}, 5^{\prime}$ phosphodiesterase activity in liver, skeletal muscle, adipose tissue and kidney. Diabetologia 4: 322-329

141. Degerman E, Smith CJ, Tornqvist H, Vasta V, Belfrage P, Manganiello VC (1990) Evidence that insulin and isoprenaline activate the c-GMP inhibited low-Km cAMP phosphodiesterase in rat fat cells by phosphorylation. Proc Natl Acad Sci USA 87: 533-53

142. Butcher RW, Baird CE, Sutherland EW (1968) Effects of antilipolytic substances on adenosine $3^{\prime}, 5^{\prime}$ monophosphate levels in isolated fat cells. J Biol Chem 243: 1705-1712

143. Illiano G, Tell GPE, Siegel MI, Cuatrecasas P (1973) Guanosine 3 ':5' -cyclic monophosphate and the action of insulin and acethylcholine. Proc Nat Acad Sci USA 70: 2443-2447

144. Vesely DL, Castro A, Levey GS (1977) Decreased rat hepatic guanylate cyclase activity in streptozotocin-induced diabetes mellitus. Diabetes 26: 308-313

145. Lopez-Aparicio P, Belfrage P, Manganiello VC, Kono T, Degerman E (1993) Stimulation by insulin of a serine kinase in human platelets that phosphorylates and activates the cGMP-inhibited cAMP phosphodiesterase. Biochem Biophys Res Commun 193: 1137-1144

146. Trovati M, Massucco P, Mattiello L et al. (1996) The insulin-induced increase of guanosine $-3{ }^{\prime}, 5$ '-cyclic monophosphate in human platelets is mediated by nitric oxide. Diabetes 45 : 768-770

147. Trovati M, Anfossi G, Massucco P et al. (1997) Insulin stimulates nitric oxide synthesis in human platelets, and, through nitric oxide, increases platelet concentrations of both guanosine- 3 ' -5 '-cyclic monophosphate and adenosine-3'-5'-cyclic monophosphate. Diabetes 46: 742-749

148. Zeng G, Quon MJ (1996) Insulin-stimulated production of nitric oxide is inhibited by wormannin. Direct measurement in vascular enothelial cells. J Clin Invest 98: 894-898

149. Axelsson KL, Andersson RGG (1983) Tolerance towards nitroglycerin, induced in vivo, is correlated to a cGMP response and an alteration in cGMP turnover. Eur J Pharmacol 88: 71-79
150. Waldman SA, Rapoport RM, Murad F (1987) Desensitization to nitroglycerin in vascular smooth muscle from rat and human. Biochem Pharmacol 35: 3525-3531

151. Arnold WP, Mittal CK, Katsuki S, Murad F (1977) Nitric oxide activates guanylate cyclase and increases guanosine $3^{\prime}, 5^{\prime}$-cyclic monophosphate levels in various tissue preparations. Proc Natl Acad Sci USA 74: 3203-3207

152. Lewicki JA, Brandwein HJ, Mittal CK, Arnold WP, Murad F (1982) Properties of purified soluble guanylate cyclase activated by nitric oxide and sodium nitroprusside. Journal of Cyclic Nucleotide Research 8: 17-25

153. Anfossi G, Massucco P, Mularoni E, Cavalot F, Mattiello L, Trovati M (1994) Effects of forskolin and organic nitrate on aggregation and intracellular cyclic nucleotide content in human platelets. Gen Pharmacol 25: 1093-1100

154. Mittal KC, Murad F (1977) Formation of adenosine 3 ',5 'monophosphate by preparations of guanylate cyclase from rat liver and other tissues. J Biol Chem 252: 3136-3140

155. Trovati M, Massucco P, Mattiello L et al. (1995) Insulin increases cyclic nucleotide content in human vascular smooth muscle cells: a mechanism potentially involved in insulin-induced modulation of vascular tone. Diabetologia 38: 936-941

156. Trovati M, Massucco P, Mattiello L et al. (1996) Studies on the insulin influence on cyclic adenosine monophosphate in human vascular smooth muscle cells: dependence on cyclic guanosine monophosphate and modulation of catecholamine effects. Diabetologia 39: $1156-1164$

157. Massucco P, Anfossi G, Mattiello L et al. (1998) Insulin acutely increases cyclic nucleotide concentrations in human vascular smooth muscle cells by stimulating nitric oxide synthesis. Eur J Clin Invest 28 (Suppl.1): A 28 (Abstract)

158. Michel T, Li GK, Busconi L (1993) Phosphorylation and subcellular translocation of endothelial nitric oxide synthase. Proc Natl Acad Sci USA 90: 6252-6256

159. Anfossi G, Mularoni E, Burzacca et al. (1998) Platelet resistance to nitrates in obesity and obese NIDDM and normal platelet sensitivity to both insulin and nitrates in lean NIDDM. Diabetes Care 21: 121-126

160. Woods JD, Edwards JS, Ritter JM (1993) Inhibition by nitroprusside of platelet calcium mobilization: evidence for reduced sensitivity to nitric oxide in essential hypertension. J Hypertens 11: 1369-1373

161. Gupta S, McArthur C, Grady C, Ruderman NB (1994) Stimulation of vascular $\mathrm{NA}^{+}-\mathrm{K}^{+}$-ATPase activity by nitric oxide: a cGMP-independent effects. A J Physiol 266:H2146-H2151

162. Gupta S, Sussman I, McArthur CS, Tornheim K, Cohen RA, Ruderman NB (1992) Endothelium-dependent inhibition of $\mathrm{Na}^{+}-\mathrm{K}^{+}$-ATPase activity in rabbit aorta by hyperglycemia: possible role of endothelium-derived nitric oxide. J Clin Invest 90: 727-732

163. Tare M, Parkington HA, Coleman HA, Nerld TO, Dusting GF (1990) Hyperpolarization and relaxation of arterial smooth muscle caused by nitric oxide derived from endothelium. Nature 346: 69-71

164. Bolotina VM, Najibl S, Palacino JJ, Pagano PJ, Cohen RA (1994) Nitric oxide directly activates calcium dependent potassium channels in vascular smooth muscle. Nature 368: 850-853

165. Dutta-Roy AK, Kahn NN, Sinha AK (1991) Interaction of receptors for prostaglandin $\mathrm{E}_{1}$ /prostacyclin and insulin in human erythrocytes and platelets. Life Sci 49: 1129-1139 
166. Kahn NN, Aurora AK, Sinha AK (1993) Up-regulation of prostaglandin $\mathrm{E}_{2} / \mathrm{I}_{2}$ receptor number and ADP ribosylation of G-alpha by insulin in platelets. FASEB J 7: 1148

167. Ishida M, Ishida T, Ono N et al. (1996) Effects of insulin on calcium metabolism and platelet aggregation. Hypertension 28: 209-212

168. Jap TS, Kwok CF, Wong MC, Chiang H (1994) The effects of in vitro and in vivo exposure to insulin upon prostaglandin $E_{1}$ stimulation of platelet adenylate cyclase activity in healthy subjects. Diabetes Research 27(1):39-46

169. Smitherman TC, Halam M, Woo J, Willerson JT, Frenkel EP (1981) Elevated thromboglobulin in peripheral venous blood of patients with acute myocardial ischemia: direct evidence of enhanced platelet reactivity in vivo. Am J Cardiol 48: 395-402

170. Willerson JT, Golino P, Eidt J, Campbell WB, Buja LM (1989) Specific platelet mediators and unstable coronary artery lesions: experimental evidence and potential clinical implications. Circulation 80: 198-205

171. Metha P, Metha J (1980) Platelet function studies in coronary heart disease: VIII. Decreased platelet sensitivity to prostacyclin in patients with myocardial ischemia. Thromb Res 18: 273-277

172. Neri Serneri GG, Fortini A, Lombardi A, Modesti PA, Abbate R, Gensini GF (1984) Reduction in prostacyclin platelet receptors in active spontaneous angina. Lancet 2: 838-841

173. Kahn NN, Mueller HS, Sinha AK (1990) Impaired prostaglandin $E_{1} / I_{2}$ receptor activity of human blood platelets in acute ischemic heart disease. Circ Res 66: 932-940

174. Kahn NN, Mueller HS, Sinha AK (1991) Restoration by insulin of impaired prostaglandin $\mathrm{E}_{1} / \mathrm{I}_{2}$ receptor activity of platelets in acute ischemic heart disease. Circ Res 68: 245-254

175. Kahn NN, Najeeb MA, Ishaq M, Rahim A, Sinha AK (1992) Normalization of impaired response of platelets to prostaglandin $E_{1} / I_{2}$ and synthesis of prostacyclin by insulin in unstable angina pectoris and in acute myocardial infarction. Am J Cardiol 70: 582-586

176. Kahn NN, Bauman WA, Sinha AK (1994) Transient decrease of binding of insulin to platelets in acute ischemic heart disease. Am J Med Sci 307: 21-26

177. Kahn NN, Bauman WA, Sinha AK (1996) Loss of high-affinity prostacyclin receptors in platelets and the lack of prostaglandin-induced inhibition of platelet-stimulated thrombin generation in subjects with spinal cord injury. Proc Nat Acad Sci USA 93: 245-249
178. Farias RN (1987) Insulin-membrane interactions and membrane fluidity changes. Biochim Biophys Acta 906: 459-468

179. Hwang DL, Yen CF, Nadler J (1993) Insulin increases intracellular magnesium transport in human platelets. $\mathbf{J}$ Clin Endocrinol Metab 76: 549-553

180. Hwang D, Yen C, Nadler J (1992) Effect of extracellular magnesium on platelet activation and intracellular calcium mobilization. Am J Hypertens 5: 700-706

181. Resnick LM, Altura BT, Gupta RK, Laragh JH, Alderman MH, Altura BM (1993) Intracellular and extracellular magnesium depletion in type 2 (non-insulin dependent) diabetes mellitus. Diabetologia 36: 767-770

182. Erickson LA, Ginsberg MH, Loskutoff DJ (1984) Detection and partial characterization of an inhibitor of plasminogen activator in human platelets. J Clin Invest 74 : 1465-1472

183. Jeanneau C, Sultan Y (1988) Tissue plasminogen activator in human megakariocytes and platelets: immunoblotting and zymographic analysis. Thromb Haemost 59: 529-534

184. Park S, Harker L, Marzec VM, Levine EG (1989) Demonstration of single chain-type plasminogen activator in platelet membrane. Blood 73: 1421-1425

185. Kahn NN, Bauman WA, Sinha AK (1995) Insulin-induced release of plasminogen activator from human blood platelets. Am J Physiol 268:H117-H124

186. Jokil R, Laimins M, Klein RL, Lyons TJ, Lopes-Virella MF, Colwell JA (1994) Platelet plasminogen activator inhibitor 1 in platelets with type II diabetes. Diabetes Care 17: 818-823

187. Pandolfi A, Iacoviello L, Capani F, Vitacolonna E, Donati MB, Consoli A (1996) Glucose and insulin independently reduce the fibrinolytic potential of human vascular smooth cells in culture. Diabetologia 39: 1425-1431

188. Stout RW (1990) Insulin and atheroma - a 20 year perspective. Diabetes Care 13: 631-654

189. Cavalot F, Russo I, Mattiello L et al. (1997) Influence of protamine on adhesion, chemotaxis and proliferation of human vascular smooth muscle cells. Diabetologia 40: $67-75$

190. Colwell JA, Gisinger C, Klein R (1992) Altered platelet function in diabetes mellitus: effect of glycemic regulation and antiplatelet agents. In: Ruderman N, Williamson J, Brownlee M (eds) Hyperglycemia, diabetes, and vascular diseases. Oxford University Press, New York, Oxford; pp $30-47$ 